\title{
Seasonal Changes in Lipid and Fatty Acid Profiles of Sakarya Chub (Squalius pursakensis) from the Melen River Basin
}

\author{
Tuğba İnan ${ }^{1}$, Deniz Ayas ${ }^{2}$, Şerife Gülsün Kırankaya ${ }^{3 *}$ \\ ${ }^{1}$ Instutute of Science, Department of Biology, Konuralp Campus, Düzce University, 81620, Düzce. Turkey. \\ ${ }^{2}$ Faculty of Fisheries, Department of Seafood Processing Technology, Mersin University, Mersin, Turkey \\ ${ }^{3}$ Faculty of Arts and Sciences, Department of Biology, Düzce Universtiy, Konuralp Campus, 81620, Düzce, \\ Turkey.
}

\section{Corresponding author: gkirankaya@gmail.com}

\begin{abstract}
In this study, total lipids and fatty acid composition of Squalius pursakensis fillet samples which were obtained from Melen River Basin during winter, spring and summer seasons were evaluated. Total lipid levels were $1.80 \%$ in winter, $2.56 \%$ in spring and $5.17 \%$ in summer. The composition of fatty acids showed that total polyunsaturated fatty acids (32.05-38.90\%) were highest, followed by monounsaturated (29.85-35.40\%) and saturated (27.10$31.23 \%$ ). The fatty acid composition of polyunsaturated fatty acids (PUFAs) in fillets of $S$. pursakensis shows a high content $n 3$ fatty acids eicosapentaenoic acid (EPA C20:5n3) and docosahexaenoic acid (DHA C22:6n3) with maximum rates of $6.70 \%$ and $16.33 \%$, respectively $(\mathrm{p}<0.05)$. The saturated fatty acid (SFA) content was dominated by palmitic acid with the maximum ratio of $19.03 \%$.
\end{abstract}

Keywords: Squalius pursakensis, fatty acids, lipids, SFA, MUFA, PUFA, Melen River

\section{Introduction}

Fish is considered as an essential and available protein source for human populations all around the World (Ghaly et al. 2013). Today, fish is an important diet component in many countries and contributes to $16.6 \%$ of animal protein consumed by the world's population (FAO 1997, FAO 2012). Additionally, fish provide important nutrients for human health such as trace elements, lipid-soluble vitamins and lipids (Roos et al. 2007, Benguendouz et al. 2017).

Lipids are biomolecules that play an important role in the body. They play the role of storage of energy and lipid-soluble vitamins. Furthermore, lipids are known to serve as integral components of biological membranes and to function as key intracellular and extracellular messengers (Simopoulos 1991). Therefore, especially unsaturated fatty acids are necessary for human health (Kaya et al. 2004). However, long-chain $n$-3 PUFAs should be obtained in the diet, since they can not be synthesized in human body (Brown 2000, Alasalvar et al. 2002).

Currently, numerous scientific researches focus on fish and fish oil fatty acids due to their various benefits on health. Fish oils are considered as the best natural source of highly unsaturated fatty acids, especially acids with more than three ethylenic groups or double bonds (Gruger et al. 1964). Studies have shown that fish lipids are rich in PUFAs, especially the EPA and DHA from $n$-3 PUFAs bonds (Ugoala et al. 2009, Sharma et al. 2010). Fish have a high capacity for the transformation of C18 essential fatty acids (EFAs); C18:3 n-3 and C18:2 n-6 to C20:5 n-3, C22:6 n-3 and C20:4 n-6 and therefore, they may be an available source of such fatty acids to consumers (Henderson and Tocher 1987). These fatty acids turned out to be very important for human health. EPA and DHA can not be 
synthesized in human boyd. They were only found in seafood such as fish. Thus, they need to be supplemented through dietary intake (Gunstone 1996). PUFAs, especially the EPA and DHA possess important beneficial properties such as reducing the risk of heart attack and human coronary artery disease (Leaf and Weber 1988, Kaya et al. 2004), lowering serum triacylglycerol levels, increasing membrane fluidity, and reducing thrombosis, the risk of coronary heart disease, hypertension, inflammation, and autoimmune disorders (von Schacky et al. 1985, Bønaa et al. 1990, Horrocks and Yeo 1999, Simopoulos 2002). Many studies show that consumption of fish oil rich in $n$-3 PUFA has beneficial effects on coronary heart disease (von Schacky and Harris 2007), hypertension (Bønaa et al. 1990), rheumatoid arthritis (Berbert et al. 2005), breast and colon cancer (Roynette et al. 2004), Alzheimer disease (Petot and Friedland 2004), inflammation and autoimmune disorders (Simopoulos 2002). n-3 PUFAs play a vital role in the development and function of the nervous system, photoreception and the reproductive system (Alasalvar et al. 2002, Sidhu 2003).

Fatty acid compositions of fish are affected by genetic properties, environmental factors and nutritional quality (Bayır et al. 2006). Although it is generally recognized that fatty acid composition may vary among fish species, there is limited information about fatty acid content of different species to be selected for diets. Additionally, it is claimed that the amount of $n-3$ PUFAs in marine fish is higher than freshwater species although studies on the fatty acid content of freshwater fish are scarce (Rahman et al. 1995).

S. pursakensis is a freshwater fish species endemic to Sakarya River, its tributaries and neighbouring basins. Although, this species is preferred as food local people, there is limited data on its nutritional value. The aim of this study was to determine the total lipid amount and fatty acid composition of $S$. pursakensis living in Melen River basin.

\section{Material and Methods}

S. pursakensis samples were obtained from four different sites in the Melen River Basin during winter, spring and summer seasons in 2018. Melen River is located on western Black Sea region in Turkey. Sampling sites selected were: Küçük Melen River (latitude: $40^{\circ} 54^{\prime} 25^{\prime \prime} \mathrm{N}$; longitude: $31^{\circ} 15^{\prime} 7^{\prime \prime} \mathrm{W}$ ), Asar Creek (latitude: $40^{\circ} 47^{\prime} 44^{\prime \prime} \mathrm{N}$; longitude: $31^{\circ} 14^{\prime} 14^{\prime \prime} \mathrm{E}$; latitude: $40^{\circ} 49^{\prime} 19^{\prime \prime} \mathrm{N}$; longitude: $31^{\circ} 11^{\prime} 43^{\prime \prime} \mathrm{E}$; latitude: $40^{\circ} 50^{\prime} 6^{\prime \prime} \mathrm{N}$; longitude: $31^{\circ} 8^{\prime} 6^{\prime \prime} \mathrm{E}$ ). Totally 30 fish specimens were caught by electrofishing. The fish samples were transported to the laboratory in ice boxes and metric measurements were carried out. The standard length ranged between $9.5 \mathrm{~cm}$ and $26.5 \mathrm{~cm}$ and the body weight from $20 \mathrm{~g}$ and $268 \mathrm{~g}$. The fish were eviscerated, the backbones were removed and edible flesh was stored at $-20^{\circ} \mathrm{C}$ for further analysis.

\section{Fat and Fatty Acids Analyses}

Lipid content was measured by the method of Bligh and Dyer (1959). Methyl esters were prepared by transmethylation using $2 \mathrm{M} \mathrm{KOH}$ in methanol and n-heptane according to the method described by Ichihara et al. (1996) with minor modification. Fatty acid composition was analyzed using a Gas Chromatography (GC) Clarus 500 device (Perkin-Elmer USA), one flame ionization detector (FID) and SGE $(60 \mathrm{~m} \times 0.32 \mathrm{~mm}$ ID BPX70 $\times 0.25 \mu \mathrm{m}$, USA or Australia) column. Injector and detector temperatures were set as $260^{\circ} \mathrm{C}$ and $230^{\circ} \mathrm{C}$ respectively. During this time, the furnace temperature was kept at $140^{\circ} \mathrm{C}$ for 8 minutes. After that, it was increased by $4^{\circ} \mathrm{C}$ per minute until $220^{\circ} \mathrm{C}$, and from $220^{\circ} \mathrm{C}$ to $230^{\circ} \mathrm{C}$ by increasing the temperature $1{ }^{\circ} \mathrm{C}$ per minute. It was kept at $230^{\circ} \mathrm{C}$ for 15 minutes to complete analysis. Sample scale was $1 \mu \mathrm{l}$ and carrier gas was controlled at $16 \mathrm{ps}$. For split flow 40, $0 \mathrm{~mL} / \mathrm{minute}$ (1:40) level was used. Fatty acids were determined using a comparison to the exit times of the FAME mix that contains 37 standard components.

\section{Conversion factor:}

Triplicate GC analyses were performed and the results were converted to mg fatty acid per $100 \mathrm{~g}$ total lipid using lipid conversion factors and then to $\mathrm{mg}$ fatty acid per $100 \mathrm{~g}$ edible portion of food using the 
total lipid content. Details of the derivation of lipid conversion factors were published by Weihrauch et al. (1975).

Factor $($ Fish $)=0.956-0.143 /$ total lipid

Fatty acid $(\mathrm{mg} / 100 \mathrm{~g})=$ Factor $\mathrm{x}$ FAME $(\%)$ x lipid level $(\%) \times 10$

Atherogenicity index (AI) and thrombogenicity index (TI):

The AI and TI linked to the fatty acid composition were calculated according to Ulbricht and Southgate (1991).

$$
\begin{aligned}
& \mathrm{AI}=\left[\left(\mathrm{a}^{*} 12: 0\right)+(\mathrm{b} * 14: 0)+(\mathrm{c} * 16: 0)\right] /\left[\mathrm{d}^{*}(\text { PUFA n-6+n-3)+e*(MUFA)+f*(MUFA-18:1) }]\right. \\
& \mathrm{TI}=\left[\mathrm{g} *(14: 0+16: 0+(18: 0)] /\left[(\mathrm{h} * \text { MUFA })+\mathrm{i}^{*}(\text { MUFA-18:1)+(m*n-6)+(n*n-3)+(n-3/n-6)] }\right.\right. \\
& \text { a, c, d, e, f=1, b=4, g=1, h, i, m=0.5 n=3 }
\end{aligned}
$$

\section{Statistical Analysis}

Obtained data were statistically analyzed using by the IBM SPSS version 22 Statistical Software. Prior to the statistical analyses for evaluating lipid and fatty acid data, all data were checked for outliers $(\mathrm{Z}$ values were checked) and homogeneity of variance was also tested with Duncan test. One-way ANOVA (Analysis of Variance) was used to evaluate the difference in the seasons.

\section{Results}

\section{Total lipid (\%)}

Lipid content of S. pursakensis is $1.80 \%$ in winter, $2.56 \%$ in spring and $5.17 \%$ in summer $(\mathrm{p}<0.05)$.

\section{Fatty acids (\%)}

In fillets $S$. pursakensis, 29 fatty acids type were determined (Table 1). The fatty acid composition of $S$. pursakensis fillets ranged between $27.10 \%$ and $31.23 \%$ for SFAs, $29.85-35.40 \%$ for MUFAs and 32.05 - $38.90 \%$ for PUFAs.

The highest proportions determined were palmitic acid (C16:0, 17.41-19.03\%), transoleic acid (C18:1 $n 9 t, 11.65-18.09 \%)$, linoleic acid (C18:2 n6cis, 7.78-11.01\%), eicosapentaenoic acid (EPA, C20:5 n3, 4.82-6.70\%) and docosahexaenoic acid (DHA, C22:6 n3, 9.91-16.33\%). It was also observed that the levels of these fatty acids changed significantly between seasons $(\mathrm{p}<0.05)$.

According to obtained data, major saturated fatty acid contributing to $\sum$ SFA was palmitic acid (C16:0). Trans oleic acid (C18:1) was the most represented of the $\sum$ MUFA. The major fatty acids identified in the PUFAs, were EPA and DHA. The highest levels of EPA and DHA were obtained during spring and summer, respectively $(\mathrm{p}<0.05)$.

MUFAs and PUFAs were dominant in the profile of fatty acids (Table 1). The proportions of $n 3$ PUFAs (ranging between 20.01 and 24.69\%) were higher than those of $n 6$ PUFAs (ranging between $11.72 \%$ and $14.21 \%$ ). According to obtained amount of $\sum$ PUFA, the highest content was found in the summer $(38.90 \%)$.

The ratio $n 3 / n 6$ varied from 1.66 to 1.81 and showed differences between seasons. Additionally, the SFA/PUFA ratio was lowest during summer (0.80) and highest during winter (0.93). DHA/EPA ratio was 1.70 in the spring and 3.31 in the summer.

\section{Fatty acids (mg/100 g)}

The level of fatty acids in $100 \mathrm{~g}$ fillets of S. pursakensis were shown in Table 2. Amount of SFAs, MUFAs and PUFAs ranged between 455.25-1161.20 mg/100g, 460.16-1396.64 mg/100g and 492.1$182.07 \mathrm{mg} / 100 \mathrm{~g}$, respectively.

The highest amounts determined were palmitic acid (C16:0, 272.84-890.39 mg/100g), transoleic acid (C18:1 $n 9 \mathrm{t}, \quad 178.87-817.40 \mathrm{mg} / 100 \mathrm{~g})$, linoleic acid (C18:2 $n 6 \mathrm{c}, 119.45-515.14 \mathrm{mg} / 100 \mathrm{~g})$, 
eicosapentaenoic acid (EPA, C20:5 n3, 74.01-231.14 mg/100g) and docosahexaenoic acid (DHA, C22:6 $n 3,152.16-764.06 \mathrm{mg} / 100 \mathrm{~g})$.

Table 1. Seasonal fatty acids profile of S. pursakensis caught from Melen River Basin (\%).

\begin{tabular}{|c|c|c|c|}
\hline Fatty acids & $\begin{array}{l}\text { Winter } \\
\bar{X} \pm S_{X}\end{array}$ & $\begin{array}{l}\text { Spring } \\
\bar{X} \pm S_{\mathrm{X}}\end{array}$ & $\begin{array}{l}\text { Summer } \\
\bar{X} \pm S_{X}\end{array}$ \\
\hline Lauric acid (C12:0) & $0.33 \pm 0.06^{\mathrm{a}}$ & $0.25 \pm 0.05^{\mathrm{a}}$ & $0.26 \pm 0.05^{\mathrm{a}}$ \\
\hline Myristic acid (C14:0) & $1.40 \pm 0.14^{\mathrm{b}}$ & $1.23 \pm 0.10^{\mathrm{b}}$ & $0.88 \pm 0.04^{\mathrm{a}}$ \\
\hline Pentadecylic acid (C15:0) & $0.40 \pm 0.01^{\mathrm{b}}$ & $0.29 \pm 0.01^{\mathrm{a}}$ & $0.29 \pm 0.01^{\mathrm{a}}$ \\
\hline Palmitic acid (C16:0) & $17.77 \pm 0.20^{\mathrm{a}}$ & $17.41 \pm 0.90^{\mathrm{a}}$ & $19.03 \pm 1.65^{\mathrm{a}}$ \\
\hline Margaric acid (C17:0) & $1.25 \pm 0.07^{\mathrm{c}}$ & $0.44 \pm 0.02^{\mathrm{b}}$ & $0.29 \pm 0.06^{\mathrm{a}}$ \\
\hline Stearic acid (C18:0) & $7.52 \pm 0.46^{\mathrm{b}}$ & $6.18 \pm 0.63^{\mathrm{a}}$ & $8.94 \pm 0.77^{\mathrm{c}}$ \\
\hline Arachidic acid (C20:0) & $0.26 \pm 0.04^{\mathrm{a}}$ & $0.27 \pm 0.04^{\mathrm{a}}$ & $0.27 \pm 0.04^{\mathrm{a}}$ \\
\hline Behenic acid (C22:0) & $0.26 \pm 0.04^{\mathrm{a}}$ & $0.40 \pm 0.05^{\mathrm{b}}$ & $0.31 \pm 0.02^{\mathrm{ab}}$ \\
\hline Lignoceric acid (C24:0) & $0.46 \pm 0.02^{\mathrm{a}}$ & $0.63 \pm 0.12^{\mathrm{b}}$ & $0.96 \pm 0.06^{c}$ \\
\hline $\begin{array}{l}\text { ISFA } \\
\text { Myristoleic acid (C14:1) }\end{array}$ & $\begin{array}{l}\mathbf{2 9 . 6 5} \\
0.32 \pm 0.03^{b}\end{array}$ & $\begin{array}{l}\mathbf{2 7 . 1 0} \\
0.23 \pm 0.06^{\mathrm{a}}\end{array}$ & $\begin{array}{l}\mathbf{3 1 . 2 3} \\
0.31 \pm 0.01^{\mathrm{b}}\end{array}$ \\
\hline Pentadecenoic (C15:1) & $0.12 \pm 0.01^{\mathrm{a}}$ & $0.14 \pm 0.02^{\mathrm{a}}$ & $0.19 \pm 0.01^{\mathrm{b}}$ \\
\hline Palmitoleic acid (C16:1) & $6.27 \pm 0.16^{\mathrm{b}}$ & $6.08 \pm 0.98^{\mathrm{b}}$ & $2.87 \pm 0.29^{\mathrm{a}}$ \\
\hline Heptadecenoic acid (C17:1) & $0.45 \pm 0.06^{\mathrm{a}}$ & $0.37 \pm 0.05^{\mathrm{a}}$ & $0.35 \pm 0.04^{\mathrm{a}}$ \\
\hline Trans oleic acid $(\mathrm{C} 18: 1 n 9 \mathrm{t})$ & $11.65 \pm 1.15^{\mathrm{a}}$ & $18.09 \pm 1.75^{\mathrm{b}}$ & $17.47 \pm 2.03^{\mathrm{b}}$ \\
\hline Oleic acid $(\mathrm{C} 18: 1 n 9 \mathrm{c})$ & $5.25 \pm 0.42^{\mathrm{c}}$ & $4.16 \pm 0.75^{\mathrm{b}}$ & $2.27 \pm 0.14^{\mathrm{a}}$ \\
\hline Vaccenic acid $(\mathrm{C} 18: 1 n 7)$ & $0.13 \pm 0.02^{b}$ & $0.09 \pm 0.01^{\mathrm{a}}$ & $0.10 \pm 0.00^{\mathrm{a}}$ \\
\hline Gadoleic acid (C20:1n9) & $0.54 \pm 0.03^{\mathrm{ab}}$ & $0.59 \pm 0.06^{\mathrm{b}}$ & $0.48 \pm 0.04^{\mathrm{a}}$ \\
\hline Erucic acid (C22:1n9) & $5.07 \pm 0.22^{\mathrm{a}}$ & $5.49 \pm 0.74^{\mathrm{a}}$ & $5.61 \pm 0.38^{\mathrm{a}}$ \\
\hline Nervonic acid (C24:1n9) & $0.17 \pm 0.01^{\mathrm{a}}$ & $0.16 \pm 0.01^{\mathrm{a}}$ & $0.20 \pm 0.00^{\mathrm{b}}$ \\
\hline इMUFA & 29.97 & 35.40 & 29.85 \\
\hline Linolelaidic Acid (C18:2n6t) & $0.17 \pm 0.01^{\mathrm{a}}$ & $0.19 \pm 0.01^{\mathrm{a}}$ & $0.17 \pm 0.02^{\mathrm{a}}$ \\
\hline Linoleic acid (C18:2n6c) & $7.78 \pm 0.26^{\mathrm{a}}$ & $9.02 \pm 0.70^{\mathrm{a}}$ & $11.01 \pm 0.79^{b}$ \\
\hline$\alpha$-Linolenic acid $(\mathrm{C} 18: 3 n 3)$ & $4.69 \pm 0.31^{\mathrm{b}}$ & $2.05 \pm 0.14^{\mathrm{a}}$ & $2.07 \pm 0.29^{\mathrm{a}}$ \\
\hline Gamma linolenic acid (C18:3n6) & $0.26 \pm 0.03^{\mathrm{a}}$ & $0.35 \pm 0.04^{\mathrm{ab}}$ & $0.43 \pm 0.05^{\mathrm{b}}$ \\
\hline Eicosatrienoic acid (C20:3n3) & $0.59 \pm 0.02^{\mathrm{a}}$ & $1.03 \pm 0.03^{\mathrm{b}}$ & $1.35 \pm 0.17^{\mathrm{c}}$ \\
\hline Dihomo- $\gamma$-linolenic acid (C20:3n6) & $0.60 \pm 0.02^{\mathrm{a}}$ & $0.74 \pm 0.05^{\mathrm{b}}$ & $0.49 \pm 0.10^{\mathrm{a}}$ \\
\hline Arachidonic acid (C20:4n6) & $2.98 \pm 0.02^{\mathrm{c}}$ & $1.06 \pm 0.11^{\mathrm{a}}$ & $1.62 \pm 0.05^{\mathrm{b}}$ \\
\hline Eicosapentaenoic acid (C20:5n3) & $4.82 \pm 0.31^{\mathrm{a}}$ & $6.70 \pm 0.72^{\mathrm{b}}$ & $4.94 \pm 0.38^{\mathrm{a}}$ \\
\hline Adrenic acid (C22:4n6) & $0.25 \pm 0.04^{\mathrm{a}}$ & $0.36 \pm 0.07^{\mathrm{a}}$ & $0.49 \pm 0.03^{b}$ \\
\hline Docosahexaenoic acid (C22:6n3) & $9.91 \pm 0.15^{\mathrm{b}}$ & $11.38 \pm 0.64^{\mathrm{b}}$ & $16.33 \pm 0.64^{\mathrm{c}}$ \\
\hline इPUFA & 32.05 & 32.88 & 38.90 \\
\hline SFA/PUFA & 0.93 & 0.82 & 0.80 \\
\hline$\Sigma n 7$ & 0.13 & 0.09 & 0.10 \\
\hline$\Sigma n 6$ & 12.04 & 11.72 & 14.21 \\
\hline$\Sigma n 3$ & 20.01 & 21.16 & 24.69 \\
\hline$\Sigma n 9$ & 22.68 & 28.49 & 26.03 \\
\hline$n 6 / n 3$ & 0.60 & 0.55 & 0.58 \\
\hline$n 3 / n 6$ & 1.66 & 1.81 & 1.74 \\
\hline DHA/EPA & 2.06 & 1.70 & 3.31 \\
\hline AI & 0.26 & 0.23 & 0.26 \\
\hline TI & 0.29 & 0.25 & 0.27 \\
\hline Unidentified & 8.33 & 4.62 & 0.02 \\
\hline
\end{tabular}

$\overline{\mathrm{X}} \pm \mathrm{S}_{\mathrm{x}}$ : means $\pm \mathrm{SD}$; the values in the same line with different superscript letter (a-b-c-d-e) are significantly different $(\mathrm{p}<0.05)$. 
Table 2. Seasonal fatty acids profile of S. pursakensis caught from Melen River Basin (mg/100g)

\begin{tabular}{|c|c|c|c|}
\hline $\begin{array}{l}\text { Conversion Factor } \\
\text { Fatty acid }(\mathbf{m g} / \mathbf{1 0 0 g})\end{array}$ & $\begin{array}{l}\mathbf{0 . 8 5 3} \\
\text { Winter }\end{array}$ & $\begin{array}{l}0.877 \\
\text { Spring }\end{array}$ & $\begin{array}{l}0.905 \\
\text { Summer }\end{array}$ \\
\hline Lauric acid (C12:0) & 5.07 & 5.61 & 12.17 \\
\hline Myristic acid (C14:0) & 21.50 & 27.61 & 41.17 \\
\hline Pentadecylic acid (C15:0) & 6.14 & 6.51 & 13.57 \\
\hline Palmitic acid (C16:0) & 272.84 & 390.88 & 890.39 \\
\hline Margaric acid (C17:0) & 19.19 & 9.88 & 13.57 \\
\hline Stearic acid (C18:0) & 115.46 & 138.75 & 418.29 \\
\hline Arachidic acid (C20:0) & 3.99 & 6.06 & 12.63 \\
\hline Behenic acid (C22:0) & 3.99 & 8.98 & 14.50 \\
\hline Lignoceric acid (C24:0) & 7.06 & 14.14 & 44.92 \\
\hline$\Sigma S F A$ & 455.25 & 608.43 & 1461.20 \\
\hline Myristoleic acid (C14:1) & 4.91 & 5.16 & 14.50 \\
\hline Pentadecenoic (C15:1) & 1.84 & 3.14 & 8.89 \\
\hline Palmitoleic acid (C16:1) & 96.27 & 136.50 & 134.28 \\
\hline Heptadecenoic acid (C17:1) & 6.91 & 8.31 & 16.38 \\
\hline Trans oleic acid $(\mathrm{C} 18: 1 n 9 \mathrm{t})$ & 178.87 & 406.14 & 817.40 \\
\hline Oleic acid $(\mathrm{C} 18: 1 n 9 \mathrm{c})$ & 80.61 & 93.40 & 106.21 \\
\hline Vaccenic acid (C18:1n7) & 2.00 & 2.02 & 4.68 \\
\hline Gadoleic acid (C20:1n9) & 8.29 & 13.25 & 22.46 \\
\hline Erucic acid $(\mathrm{C} 22: 1 n 9)$ & 77.84 & 123.26 & 262.48 \\
\hline Nervonic acid (C24:1n9) & 2.61 & 3.59 & 9.36 \\
\hline इMUFA & 460.16 & 794.77 & 1396.64 \\
\hline Linolelaidic Acid (C18:2n6t) & 2.61 & 4.27 & 7.95 \\
\hline Linoleic acid (C18:2n6c) & 119.45 & 202.51 & 515.14 \\
\hline$\alpha$-Linolenic acid (C18:3n3) & 72.01 & 46.02 & 96.85 \\
\hline Gamma linolenic acid (C18:3n6) & 3.99 & 7.86 & 20.12 \\
\hline Eicosatrienoic acid (C20:3n3) & 9.06 & 23.12 & 63.16 \\
\hline Dihomo- $\gamma$-linolenic acid (C20:3n6) & 9.21 & 16.61 & 22.93 \\
\hline Arachidonic acid (C20:4n6) & 45.75 & 23.80 & 75.80 \\
\hline Eicosapentaenoic acid (C20:5n3) & 74.01 & 150.42 & 231.14 \\
\hline Adrenic acid (C22:4n6) & 3.84 & 8.08 & 22.93 \\
\hline Docosahexaenoic acid (C22:6n3) & 152.16 & 255.50 & 764.06 \\
\hline ¿PUFA & 492.10 & 738.20 & 1820.07 \\
\hline$\Sigma n 6$ & 184.86 & 263.13 & 664.86 \\
\hline$\Sigma n 3$ & 307.23 & 475.07 & 1155.21 \\
\hline$\Sigma n 9$ & 348.23 & 639.63 & 1217.90 \\
\hline$\Sigma n 7$ & 2.00 & 2.02 & 4.68 \\
\hline Unidentified & 127.90 & 103.72 & 0.94 \\
\hline
\end{tabular}

The amount of $n 3$ PUFAs reached $1155.21 \mathrm{mg} / 100 \mathrm{~g}$ during the summer; although amount of $n 6$ PUFAs (ranging between 184.86 and $664.86 \mathrm{mg} / 100 \mathrm{~g}$ ) were lower than $n 3$ PUFAs in all seasons. 


\section{Discussion}

Fish are often classified on the basis of their fat content as, lean, low-fat, medium-fat and fatty fish. In the Lambertsen classification, fat content is lower than $2 \%$ by weight in lean fish, between $2-4 \%$ by weight in low-fat fish, $4-8 \%$ by weight in medium-fat fish and higher than $8 \%$ by weight in fatty fish (Lambertsen 1978). Whereas in the Polish standards fat content is lower than $2 \%$ in lean fish, between 2-7\% in low-fat fish, 7-15\% in medium-fat fish and higher than 15\% in fatty fish (Polish Standard PNA-86770 1999). Fish lipid content varies according to species, seasons, geographic origin as well as age and sexual maturity in the same species (Rahman et al. 1995). Lipid content of S. pursakensis varied between $1.80 \%$ and 5.17 , therefore it can be considered medium fat fish especially during summer season. Lipid content of $S$. pursakensis is $1.80 \%$ in winter, $2.56 \%$ in spring and $5.17 \%$ in summer ( $\mathrm{p}<0.05$ ). According to Lambertsen and Polish standards, S. pursakensis can be accepted as low-fat fish in terms of annual variations in fat content In fish, lipids are stored in the liver and muscle tissues, and the stored lipids are transported from the liver and muscles to other parts of the body such as gonads when they need (Jangaard et al. 1967). After the breeding season, fish restart an intensive feeding period in order to gain their condition lost in their breeding activities. During summer and autumn seasons, metabolic rate increases and lipids are stored for using in winter and next breeding season. As the gonads begin to develop, storaged lipids in the liver, muscle and other tissues transport to the gonads, thus the lipid content is increased in gonads but decreased in the liver and muscle tissues. Additionally, temperature is a significant environmental factor affecting the feeding activities of fish which is poikilotherm animals.

In the present study, the PUFA content (32.02-38.90\%) was generally higher than MUFA (29.85-35.40) and SFA (27.10-31.23). Similarly, Ateş (2013) found higher rates of PUFA in S. pursakensis caught from upper Sakarya River. Kaçar and Başhan (2016) also reported higher PUFA content in Carassius gibelio, Carassius auratus, Liza abu, Chalcalburnus mossulensis and Chondrostoma regium, whereas MUFA were higher amount in Aspius vorax, Carassobarbus luteus, Acanthobrama marmid, Cyprinion macrostomum and Capoeta trutta from Atatürk Dam Lake. However, Rahman et al. (1995) found that MUFA content was higher than SFA and PUFA in many freshwater fish species especially in tropical waters.

The highest content of total PUFAs was found in the summer, while Ateş (2013) found higher PUFA contents for the same species during spring and autumn (50.039-55.512\%). Concerning total PUFAs, lower contents was found for S. pursakensis in Melen River Basin than upper Sakarya River Basin. Fish need PUFAs to provide tolerance to low water temperatures. Decreases in PUFA concentrations in lipids would therefore be expected in warmer waters (Rahman et al. 1995).

EPA and DHA were found to be higher rate in the present study. Similarly, Ateş (2013) also found higher EPA and DHA ratios for S. pursakensis caught from Upper Sakarya River. According to data obtained by Ateş (2013), EPA ratio was varied from $6.59 \%$ to $15.469 \%$, and ratio of DHA was between $20.534 \%$ and $25.604 \%$. In tropical waters, EPA and DHA ratios in freshwater fish species were found lower than 2\% (Rahman et al. 1995). EPA and DHA are also dominant in marine fish species. Bayır et al. (2006) found that EPA ratio in some marine fish ranged between 6.02\% (Salmon) and 18.74 (twobanded bream), and ratio of DHA varied between $10.57 \%$ (horse mackerel) and 25.85\% (Anchovy). Similarly, EPA and DHA proportions in Sardina pilchardus in Algerian coasts were found 7.74-15.75\% and 16.83-28.34\%, respectively (Benguendouz et al. 2017). EPA is the most essential fatty acid of the $n 3$ series for the human diet (Chen et al. 1995). On the other hand, DHA is considered more efficient then EPA as an essential fatty acid, because it improves the health value of fish (Benguendouz et al. 2017). The fatty acid composition in fish can vary depending on fishing ground and can be affected by environmental and geographical conditions (Saito et al. 1997).

The SFA/PUFA ratio estimated in this study (0.80-0.93) were higher than the one estimated by Ateş (2013) (0.46-0.65), for S. pursakensis. The $n 3 / n 6$ fatty acid ratio is the best index for evaluating the 
nutritional value of fish species (Piggott and Tucker, 1990). In the marine fish, this ratio is ranged from 1.3 (butterfish) and 15.2 (Atlantic cod), while in freshwater fish $n 3 / n 6$ fatty acid ratio varied between 0.6 (carp) and 5.6 (black bass) (Hearn et al. 1987). In this study, the $n 3 / n 6$ ratios ranged between 1.66 and 1.81 However, Ateş (2013) found that $n 3 / n 6$ fatty acid ratio varied between 3.95 and 5.412. The $n 3 / n 6$ fatty acid profile in $S$. pursakensis is convenient to obtained data for freshwater fish.

The amount of PUFAs in the muscle filets of $S$. pursakensis varied between 74.01-231.14 mg/100g for EPA and 152.16-764.06 mg/100g for DHA. Kmínková et al. (2001) found that the amount of EPA and DHA in muscle tissue of carp were $82.2-149.2 \mathrm{mg} / 100 \mathrm{~g}$ and $24.5-56.2 \mathrm{mg} / 100 \mathrm{~g}$, respectively. According to these values, S. pursakensis has higher amount of $n 3$ PUFAs. According to British Nutrition Foundation standards, it is recommended that people who have a balanced and healthy diet should consume $0.2 \mathrm{~g}$ of EPA + DHA per day (HMSO 1994). Obtained results in the present study suggest that EPA and DHA required for a balanced and healthy nutrition can be provided with $100 \mathrm{~g}$ daily consumption of S. pursakensis species in all seasons.

Steady growth of human populations results in higher fish consumption, in part due to their $n 3$-PUFAs, which plays a decisive role in the preventing cardiovascular diseases (Leaf and Weber 1988, Bouderouna et al. 2011) and neurodegenerative syndromes such as Alzheimer's disease (Moyad 2005). Therefore, when fish are suggested as a means of improving health, both the lipid content and the PUFA profile should be considered (Rahman et al. 1995). According to the data obtained, S. pursakensis is a good source in terms of EPA and DHA.

\section{Acknowledgements}

This study was supported by the Scientific Research Foundation of Düzce University (Project number: 2019.05.01.917).

\section{References}

Agren, J., Mute, P., Hanninen, O., Herranen, J., Pentila, I. (1987). Seasonal Variations of Lipid Fatty Acids of Boreal Freshwater Fish Species, Comperative Biochemistry and Physiology, 88(B), 905-909.

Alasalvar, C., Taylor, K.D.A, Zubcov, E., Shahidi, F., Alexis, M. (2002). Differentation of cultured and wild sea bass (Dicentrarchus labrax): total lipid content, fatty acid and trace mineral composition, Food Chemisrty, 79, $145-150$.

Ateş, E. (2013). Determination of Fatty Acids Cahanges in Fish Species Living in Upper Sakarya River Basin. [MSc thesis] Afyon Kocatepe University, Institute of Science, Afyon. (in Turkish).

Bayır, A., Haliloğlu, İ., Sirkecioğlu, A.N., Aras, M. (2006). Fatty acid composition in some selected marine fish species living in Turkish waters, Journal of Science of Food and Agriculture, 86, 163-168.

Benguendouz, A., Bouderouna, K., Bouterfa, A., Belabes, M., Bekada, A., Sioriki, E., Zabetakis, I. (2017). Fatty acid profile and assessment of heavy metals content of Sardina pilchardus captured in the Algerian coast, Iranian Journal of Fisheries Sciences, 16(3), 1201-1029.

Bennion, M. (1980). Introductory Foods, 7th edn. Macmillan, New York, USA.

Bligh, E.G., Dyer, W.J. (1959). A rapid method of total lipid extraction and purification, Biochemistry and Cell Biology, 37(8), 911-917.

Bønaa K.H., Bjerve K.S., Straume B., Gram I.T, Thelle D. (1990). Effect of eicosapentaenoic and docosahexaenoic acids on blood pressure in hypertension. A population-based intervention trial from the Troms $\emptyset$ study, The New England Journal of Medicine, 322(12), 795-801.

Berbert, A.A., Kondo C.R., Almendra C.L., Matsuo T., Dichi, I. (2005). Supplementation of fish oil and olive oil in patients with rheumatoid arthritis, Nutrition, 21(2), 131-6. 
Bouderouna, K., Mourot, J., Benmehdi-Tabet-Aoull, F., Selselet-Attou, G. (2011). The effect of season and site of catch on morphometric characteristics, mineral content and fatty acids of sardines (Sardina pilchardus) caught on the Algerian coast, Journal of Aquatic Food Product Technology, 20(4), 412-420.

Brown A. (2000). Understanding Food. Fish and Shellfish. Wadsworth /Thomson Learning, USA, 299 pp.

Chen, I. C., Chapman, F. A., Wei, C. I., Porteir, K. M. and O’Keefe, S. F. (1995). Differentation of cultured and wild stureon (Acipenser oxyrinchus desotoi) based on fatty acid composition, Journal of Food Science, 60(3), 631635.

FAO (1997). Review of the State of World Aquaculture. FAO Fisheries Circular No. 886, Rev. 1. Rome, Italy.

FAO. (2012). The state of world fsheries and aquaculture. FAO Fisheries and Aquaculture Department. Rome, Italy.

Ghaly, A. E., Ramakrishnan, V. V., Brooks, M. S., Budge, S. M. and Dave, D. (2013). Fish processing wastes as a potential source of proteins, amino acids and oils: A critical review. Journal of Microbial and Biochemical Technology, 5(4), 107-129.

Gruger, E.H., Nelson, R.W., Stansby, M.E. (1964). Fatty acid composition of oils from 21 species of marine fish, freshwater fish and shellfish, Journal of the American Oil Chemists Society, 41(10), 662-667

Gunstone F. (1996). Fatty Acid and Lipid Chemistry. Blackie Acaademics and Professional. London, U.K.

Hearn, T. L., Sgoutas, S. A., Hearn, J. A. and Sgoutas, D. S. (1987). Polyunsaturated fatty acids and fat in fish flesh for selecting species for health benefits, Journal of Food Sciences, 52: 1209-1211.

Henderson, R.J., Tocher, D.R. (1987). The lipid composition and biochemistry of freshwater fish. Progress in Lipid Research, 26, 281-347.

HMSO. (1994). Nutritional aspects of cardiovascular disease. Report on health and social subjects, no. 46. London: HMSO.

Horrocks, L.A., Yeo, Y.K. (1999). Health benefits of docosahexaenoic acid DHA. Pharmacological Research, 40, 211-225.

Ichihara, K., Shibahara, A., Yamamoto, K., Nakayama, T. (1996). An improved method for rapid analysis of the fatty acids of glycerolipids. Lipids, 31, 535-539.

Jangaard, P.M., Brockerhoff, H., Burger, R.D., Hoyle, R.J, (1967). Seasonal Changes in General Condition and Lipid Content of Cod from Inshare Waters, Journal of Fisheries Research Board of Canada, 24, 607-612.

Kaçar, S., Başhan, M. (2016). Comparison of lipid contents and fatty acid profiles of freshwater fish from the Atatürk Dam Lake, Turkish Journal of Biochemistry, 41(3), 150-156.

Kaya, Y., Duyar, H.A., Erdem, M.E. (2004). Importance of Fish Fatty Acids for Human Health, Ege Universtiy Journal of Fisheries and Aquatic Sciences, 21(3/4), 365-370. (in Turkish)

Kmínková, M., Winterová, R., Kučera, J. (2001). Fatty acids in lipids of carp (Cyprinus carpio) tissues, Czech Journal of Food Science, 19, 177-181.

Lambertsen, G. (1978). Fatty acid composition of fish fats. Comparison based on eigth fatty acids. Fisk. Dir. Skr., Ser. Ernæ ring, 1(4): 105-116.

Leaf, A., Weber, P.C. (1988). Cardiovascular effects of n3 fatty acids. New England Journal of Medicine, 318(9), 549-557.

Moyad, M.A. (2005). An introduction to dietary/supplemental omega-3 fatty acids for general health and prevention: Part II., Urologic Oncology, 23(1), 36-48.

Petot G.J, Friedland R.P. (2004). Lipids, diet and Alzheimer disease: an extended summary, Journal of Neurological Sciences, 226(1-2), 31-33. 
Piggott, G. M. and Tucker, B. W. (1990). Effects of Technology on Nutrition, Marcel Dekker, New York.

Polish Standard PN-A-86770 (1999). Fish and fishery products - terminology. (in Polish).

Rahman, S.A., Huah, T.S., Hassan, O., Daud, N.M. (1995). Fatty Acid composition of some Malaysian freshwater fish, Food Chemistry, 54, 45-49.

Roos, N., Wahab, M.A., Chamnan C., Thilsted S.H. (2007). The Role of Fish in Food-Based Strategies to Combat Vitamin A and Mineral Deficiencies in Developing Countries, Journal of Nutrition, 137,1106-1109.

Roynette C.E., Calder, P.C., Dupertuis, Y.M., Pichard C. (2004). n-3 polyunsaturated fatty acids and colon cancer prevention. Clinical Nutrition, 23(2), 139-51.

Saito, H., Ishihara, K., Murase, T. (1997). The fatty acid composition in tuna (Bonito, Euthynnus pelamis) caught at three different localities from tropics to temperate, Journal of the Science of Food and Agriculture, 73(1), 5359.

Sharma P., Kumar V., Sinha A.K., Ranjan J., Kithsiri H.M., Venkateshwarlu G. (2010). Comparative fatty acid profiles of wild and farmed tropical freshwater fish rohu (Labeo rohita). Fish Physiology and Biochemistry, 36(3), $411-417$.

Sidhu K.S. (2003). Health benefits and potential risks related to consumption of fish or fish oil. Regulatory Toxicology and Pharmacology, 38(3), 336-344.

Simopoulos, A.P. (1991). Omega-3 fatty acids in health and disease and in growth and development, American Journal of Clinical Nutrition, 54, 438-463.

Simopoulos, A.P. (2002). omega-3 fatty acids in inflammation and autoimmune diseases, Journal of American College of Nutrition, 21(6), 495-505.

Ugoala, C.H., Naukwe G.I., Audu T.O. (2009). Fatty acids composition and nutritional quality of some freshwater fishes. Nature Proc., Doi:10.1038/npre. 32391.1.

Ulbricht, T.L., Southgate, D.A.T. (1991). Coronary heart disease: Seven dietary factors. Lancet, 338, 985-992.

von Schacky C., Fischer S., Weber P.C. (1985). Long-term effects of dietary marine omega-3 fatty acids upon plasma and cellular lipids, platelet function, and eicosanoid formation in humans, Journal of Clinical Investigation, 76(4), 1626-1631.

von Schacky C., Harris W.S., (2007). Cardiovascular benefits of omega-3 fatty acids, Cardiovascular Research, 73(2), 310-315.

Weihrauch, J.L., Posati, L.P., Anderson, B.A., Exler, J. (1975). Lipid conversion factors for calculating fatty acid contents of foods, Journal of American Chemical Society, 54, 36-40. 